\title{
Identification of Persistent Defects in Insulin Receptor Structure and Function in Capillary Endothelial Cells from Diabetic Rats
}

\author{
Ching Fai Kwok, Barry J. Goldstein, Dirk Muller-Wieland, Tian-Shing Lee, C. Ronald Kahn, and George L. King \\ Research Division, Joslin Diabetes Center, Department of Medicine, Brigham and Womens Hospital, and Harvard Medical School, \\ Boston, Massachusetts 02215
}

\begin{abstract}
Insulin actions and receptors were studied in capillary endothelial cells cultured from diabetic BB rats and their nondiabetic colony mates. The endothelial cells from diabetic rats of $\mathbf{2}$ mo duration had persistent biological and biochemical defects in culture. Compared with normal rats, endothelial cells from diabetic rats grew $\mathbf{4 4 \%}$ more slowly. Binding studies of insulin and insulin-like growth factor I (IGF-I) showed that cells from diabetic rats had $50 \%$ decrease of insulin receptor binding (nondiabetic: $4.6 \pm 0.7$; diabetic: $2.6 \pm 0.4 \%$ per milligram protein, $P<0.01$, which was caused by a $50 \%$ decrease in the number of binding sites per milligram protein, whereas IGF-I binding was not changed. Insulin stimulation of 2-deoxy-glucose uptake and $\alpha$-aminoisobutyric acid uptake were also severely impaired with a $80-90 \%$ decrease in maximal stimulation, in parallel with a $62 \%$ decrease of insulin-stimulated autophosphorylation $(P<0.05) .{ }^{125}$ I-insulin cross-linking revealed an $140-\mathrm{kD} \alpha$ subunit of the insulin receptor similar to that in cells from nondiabetic rats, although bands at $>200 \mathrm{kD}$ were also detected. The molecular weight of the insulin receptor $\beta$ subunit (by SDS-PAGE) was smaller in cells from diabetic than from normal rats $(88-90$ vs. $95 \mathrm{kD})$. Neuraminadase treatment of the partially purified insulin receptors decreased the molecular weight of the insulin receptors from nondiabetic rats to a greater degree than its diabetic counterpart. In contrast, Northern blot analysis of insulin receptor mRNAs using human cDNA probes revealed two species of 9.4 and $7.2 \mathrm{~kb}$ with no difference in mRNA abundance between cells from diabetic and nondiabetic rats. We conclude that the exposure of capillary endothelial cells to a diabetic milieu in vivo can cause specific and persistent changes in the insulin receptor and insulin action.
\end{abstract}

\section{Introduction}

Microangiopathy is a major cause of morbidity in patients with diabetes mellitus. The pathogenesis of diabetic microangiopathy remains enigmatic, despite the acquisition of a great deal of knowledge concerning functional (1-3), biochemical

Part of this study has been presented at the 46th Annual Meeting of the American Diabetes Association, June 1986, Anaheim, CA.

Address reprint requests to Dr. George L. King, Research Division, Joslin Diabetes Center, One Joslin Place, Boston, MA 02215.

Received for publication 22 May 1987 and in revised form $10 \mathrm{Au}$ gust 1988

J. Clin. Invest.

(C) The American Society for Clinical Investigation, Inc.

$0021-9738 / 89 / 01 / 0127 / 10 \$ 2.00$

Volume 83, January 1989, 127-136
(4), and morphological changes (5) in the vasculature of diabetic patients. These characteristic changes include increased regional vascular flow $(1,2)$, increased microvascular permeability (3), capillary basement membrane thickening (4), and the presence of microaneurysms and neovascularization (5). It is likely that endothelial cells play an important role in the development of microangiopathy. Cellular abnormalities in growth have been reported previously in fibroblast and arterial smooth muscle cells cultured from diabetic animals and patients (6-8), but specific biochemical abnormalities have not been identified in the vascular cells. Moreover, no study has characterized the abnormalities of capillary endothelial cells from diabetic human or animals. Abnormalities in insulin actions and receptor functions have recently been found in nonvascular tissues isolated from diabetic humans and animals (9-12). Because capillary endothelial cells have been shown previously to be insulin sensitive (13), abnormalities in these cells from diabetic animals may also occur.

This study is a comparative analysis of capillary endothelial cells from diabetic and nondiabetic rats with respect to growth and insulin action, using BB and streptozotocin-induced diabetic rats. In the $\mathrm{BB}$ rat model of autoimmune insulin-dependent diabetes, $\sim 60 \%$ of the BB rats develop clinical ketosis prone diabetes at the age of 60-100 d (14). A decrease in the retinal pericyte/endothelial cell ratio and thickening of capillary basement membrane similar to those reported in diabetic patients have been observed $(15,16)$. In this work, we find a persistent biochemical abnormality in the insulin receptor and insulin action of cultured capillary endothelial cells from diabetic rats.

\section{Methods}

Materials. Tissue culture plasticware were obtained from Costar Corp. (Cambridge, MA). DME and Earle's media were from Irvine Scientific (Santa Ana, CA). Plasma-derived horse serum was from HyClone Laboratories (Logan, UT). Fibronectin and oligo (dT)-cellulose (type III) were purchased from Collaborative Research (Lexington, MA); collagenase was from Worthington Biochemicals (Freehold, NJ). ${ }^{125} \mathrm{I}-\mathrm{A} 14-$ insulin, ${ }^{125} \mathrm{I}$-IGF-I, methyl- $\left[{ }^{3} \mathrm{H}\right]$ thymidine, and $\left[{ }^{14} \mathrm{C}\right] 2$-deoxy-glucose were purchased from Amersham Corp. (Arlington Heights, IL); porcine insulin was from Elanco (Indianapolis, IN); insulin-like growth factor I (IGF-I) ${ }^{1}$ was from Imcell (Terre Haute, IN); and $\left[{ }^{14} \mathrm{C}\right] \alpha$ amino-isobutyric acid was from New England Nuclear (Boston, MA). Disuccinimidyl suberate (DSS) was purchased from Pierce Chemical Co. (Rockford, IL). BioTrace RP Nylon paper was from Gelman Sciences, Inc., (Ann Arbor, MI). SP 64 vectors were from Promega Biotec (Madison, WI). Hexamer priming kit Prime Time was from International Biotechnologies (New Haven, CT). Reagents for electrophoresis were obtained from Bio-Rad Laboratories (Rich-

1. Abbreviations used in this paper: DSS, disuccinimidyl suberate; IGF-I, insulin-like growth factor I; 2-DG-2-deoxy-D-glucose; WGA, wheat-germ agglutinin. 
mond, CA), and other reagents were from Sigma Chemical Co. (St. Louis, MO).

Diabetic rats. The animals used in this study were BB rats obtained from Dr. Arthur Like, University of Massachusetts, Worcester, MA. Diabetic animals were diagnosed on the basis of $4+$ glycosuria and a plasma glucose in excess of $200 \mathrm{mg} / \mathrm{dl}$. Five groups of diabetic BB rats (six rats per group) were studied. All diabetic rats were treated with a single daily injection of protamine zinc insulin suspension with the dose of insulin adjusted daily to prevent ketonuria and severe weight loss. Their mean age of death was $160 \mathrm{~d}$, range 146 to $177 \mathrm{~d}$. The mean duration of diabetes was $54 \mathrm{~d}$, range from 42 to $67 \mathrm{~d}$. The mean plasma glucose value of diabetic rats on the day of death was $364 \mathrm{mg} / \mathrm{dl}$ (range 339 to $400 \mathrm{mg} / \mathrm{dl}$ ).

Nondiabetic control rats. Five groups of nondiabetic rats (six rats per group) were used as controls. They were all derived from diabetic forebears. One group (six rats), through inbreeding, is composed of diabetic-prone $\mathrm{BB}$ rats that are now resistant to the disease. The other four groups ( 24 rats total) were diabetic-prone as the diabetic BB rats and were from the colony mates of the diabetic rats, except they had not developed diabetes at the time of killing. Because diabetic resistant groups and diabetic-prone groups behave the same with respect to insulin actions and receptor binding, they were considered together in this study. Cultures were prepared from these rats at the age of 130-150 d, comparable to the diabetic groups.

Streptozotocin-induced diabetic rats. Sprague-Dawley rats weighing $175-200 \mathrm{~g}$ were treated with $70 \mathrm{~g} / \mathrm{kg}$ wt streptozotocin. All rats with glucose $>300 \mathrm{mg} / \mathrm{dl}$ were designated as diabetic and $50 \%$ of the diabetic rats survived for $8 \mathrm{wk}$ without the use of insulin. Six rats with and without diabetes were maintained for $8 \mathrm{wk}$ and then killed. The capillaries were isolated as described below.

Capillary endothelial cell cultures. Cells were prepared from epididymal fat pads of rats killed with an overdose of $\mathrm{CO}_{2}$ using a method similar to the one described for retinal endothelial cells (13). Briefly, the fat pads were dissected and minced into small pieces and incubated with $0.2 \%$ collagenase in a PBS. This mixture was homogenized and centrifuged with the supernatant discarded. The pellet was resuspended in Earle's medium and filtered through three nylon screens of decreasing mesh sizes of 210,88 , and $53 \mu \mathrm{m}$. Digested capillaries retained by the last nylon screen were collected by centrifugation and plated on fibronectin-coated tissue culture dishes in DMEM containing $100 \mathrm{mg} / \mathrm{dl}$ of glucose with $5 \%$ plasma-derived horse serum. The cells were then harvested by treatment with $0.05 \%$ trypsin with $0.2 \%$ EDTA and replanted in fibronectin-coated tissue culture dishes. The cell identity and the homogeneity of the culture were confirmed by phase-contrast microscopic morphology and the presence of Factor VIII antigen by immunofluorescence with specific antibodies (17). No significant differences in growth or characteristics of insulin receptor were found between cells from the 5th to 30th passage, which were used in these studies. For cells used in testing the effect of elevated glucose level, endothelial cells were incubated in $400 \mathrm{mg} / \mathrm{dl}$ of D-glucose for 3-10 mo with the media changed every 2-3 d.

Growth parameters. Cell growth rates were measured by seeding the same number of trypsinized cells into 12 -well $\left(4.9 \mathrm{~cm}^{2}\right)$ plates and cell counts were made $24 \mathrm{~h}$ later and every other day for the course of the experiment. Cells were counted in an electronic cell counter (Coulter Electronics, Hialeah, FL) after trypsin dissociation.

Binding studies. Binding of ${ }^{125} \mathrm{I}$-insulin to capillary endothelial cell monolayers of diabetic and non-diabetic BB rats was measured as described previously (18). Briefly, confluent cell monolayers in 6-well plates were washed with Hepes buffer, $\mathrm{pH} 7.6$, and then incubated for 4 $\mathrm{h}$ at $15^{\circ} \mathrm{C}$, with $1 \mathrm{ml}$ of Hepes buffer containing $0.5 \% \mathrm{BSA}, 0.15 \mathrm{ng} / \mathrm{ml}$ of ${ }^{125} \mathrm{I}$-insulin (specific activity $350 \mu \mathrm{Ci} / \mu \mathrm{mol}$ ) and various concentrations of unlabeled insulin. The specific binding of ${ }^{125} \mathrm{I}$-insulin was calculated by subtracting the amount of radioactivity bound in the presence of a high concentration of unlabeled porcine insulin (1.6 $\times 10^{-6} \mathrm{M}$ ) from the total radioactivity bound to cells. Protein content was determined in duplicate by method of Lowry et al. (19). The same procedure was used to measure the binding of ${ }^{125}$ I-IGF-I.
Determination of 2-deoxy-D-glucose (2DG) uptake (20). Cell monolayers were rinsed twice with PBS and incubated in DME with $0.5 \%$ BSA for $12 \mathrm{~h}$ and then incubated in glucose-free DME for $2 \mathrm{~h}$ at $37^{\circ} \mathrm{C}$ in humidified $5 \% \mathrm{CO}_{2}$, and $95 \%$ air. The cells were washed with PBS and then incubated with Krebs-Ringer phosphate-2.5\% BSA with or without various concentrations of insulin for $30 \mathrm{~min}$. $\left[{ }^{14} \mathrm{C}\right] 2 \mathrm{DG}(0.5$ $\mu \mathrm{Ci} /$ well) was then added to the cells and incubated for $10 \mathrm{~min}$. The radioactive medium was removed and cells washed with ice-cold PBS three times. The cells were solubilized with $1 \mathrm{ml} 0.1 \%$ SDS and counted in liquid scintillation counter (1215 Rackbeta II; LKB Instruments, Gaithersburg, MD). The data were normalized to protein concentration.

Determination of $\alpha$-amino isobutyric acid (AIB) uptake (21). Cultured endothelial cells were rinsed with PBS and incubated in DME with $0.5 \% \mathrm{BSA}$ at $37^{\circ} \mathrm{C}$ for $12 \mathrm{~h}$ as previously described (21). After washing and incubating for another $4 \mathrm{~h}$ in PBS with 0.5\% BSA and 5 $\mathrm{mM}$ glucose in the presence or absence of various concentrations of insulin, $\left[{ }^{14} \mathrm{C}\right] \mathrm{AIB}(0.5 \mu \mathrm{Ci} /$ well $)$ was added to the mixture. After $1 \mathrm{~h}$, the medium was quickly aspirated and the cells were washed three times with ice-cold PBS and solubilized with $0.1 \%$ SDS. The cell extract was counted in a scintillation counter.

$\left[{ }^{3} \mathrm{H}\right]$ Thymidine incorporation into DNA. Endothelial cells were grown to confluence at $37^{\circ} \mathrm{C}$ in 12 -well plates $\left(4.9 \mathrm{~cm}^{2} /\right.$ well $)$. The growth media was then replaced with DME containing 0.5\% BSA for $24 \mathrm{~h}$. The indicated hormones were added to each well and incubated for $18 \mathrm{~h}$ before pulsing with $\left[{ }^{3} \mathrm{H}\right]$ thymidine, $2 \mu \mathrm{Ci} / \mathrm{ml}$ for $30 \mathrm{~min}$ at $37^{\circ} \mathrm{C}$. The cells were then solubilized in $0.1 \%$ SDS and precipitated with $10 \%$ cold TCA and counted in liquid scintillation fluid (22).

Affinity labeling (23). Binding was performed with ${ }^{125}$ I-insulin (2.5 $\mathrm{ng} / \mathrm{ml}, 350 \mu \mathrm{Ci} / \mathrm{mmol}$ ) at $15^{\circ} \mathrm{C}$ for $4 \mathrm{~h}$ in the presence and absence of unlabeled insulin as described previously using DSS. The cell lysates were boiled in Laemmli solution containing $0.1 \mathrm{M}$ DTT and then analyzed in $0.1 \%$ SDS, $7.5 \%$ polyacrylamide gels using a discontinuous system with molecular weight standards of myosin, 200,000; $\beta$-galactosidase, 116,250; phosphorylase B, 92,500; BSA 66,200; and ovalbumin, 45,000 . The gels were stained with $0.25 \%$ Coomassie brilliant blue and autoradiographed with Kodak X-Omat film for 3 wk.

Insulin receptor phosphorylation. The insulin receptor autophosphorylation assay was performed using Triton X-100 to solubilize the cells, and purification of the receptor on a wheat-germ agglutinin (WGA) agarose column (24). The partially purified receptor after normalization for insulin binding was incubated with different concentrations of insulin for $30 \mathrm{~min}$ at room temperature in the presence of 5 $\mathrm{mM} \mathrm{MnCl}$. The phosphorylation reaction was initiated by adding 50 $\mu \mathrm{M}$ cold ATP and $100 \mu \mathrm{Ci} /$ tube $^{32} \mathrm{P}$-ATP. After $8 \mathrm{~min}$, the reaction was stopped by the addition of cold solution containing $50 \mathrm{mM} \mathrm{NaF}, 20$ $\mathrm{mM} \mathrm{Na} \mathrm{P}_{2} \mathrm{O}_{7}, 5 \mathrm{mM}$ EDTA, and $50 \mathrm{mM}$ ATP and then immunoprecipitated with antireceptor antibody (serum $B 9$ at 1:200). The immune complexes were precipitated with protein A (Calbiochem-Behring Corp., La Jolla, CA). After being washed three times, the pellets were solubilized and boiled in Laemmli buffer and submitted to SDS, 7.5\% PAGE under reducing conditions (0.1 M DTT). The phosphorylated $\beta$ subunit of the insulin receptor was identified by autoradiography and quantitated by scanning densitometry of the autoradiograms.

Neuraminidase treatment of insulin receptors was performed by incubating WGA-purified receptors with $2 \mathrm{U} / \mathrm{ml}$ neuraminidase at $37^{\circ} \mathrm{C}$ for $30 \mathrm{~min}$ in the presence of $0.1 \mathrm{mg} / \mathrm{ml}$ aprotinin. Autophosphorylation and identification of insulin receptor $\beta$ subunits was then performed as described above.

Northern blot analysis of insulin receptor $m R N A$. Endothelial cell RNA was isolated by the method of Han et al. (25) and poly(A) ${ }^{+}$RNA was selected by two passages over oligo(dT)-cellulose (26). Poly(A) ${ }^{+}$ RNA was then separated on a $1 \%$ agarose-2.2 $\mathrm{M}$ formaldehyde gel and transferred to BioTrace RP Nylon paper with $10 \times \operatorname{SSC}(1 \times \operatorname{SSC}=0.15$ $\mathrm{M} \mathrm{NaCl} / 0.015 \mathrm{M} \mathrm{Na}$ citrate). Filters were baked at $80^{\circ} \mathrm{C}$ for $2 \mathrm{~h}$, soaked at $65^{\circ} \mathrm{C}$ for $1 \mathrm{~h}$ in $0.1 \times \mathrm{SSC} / 0.5 \%$ (wt/vol) SDS, and then prehybridized at $42^{\circ} \mathrm{C}$ for $16 \mathrm{~h}$ in a solution containing $50 \%$ formamide, $10 \%$ dextran sulfate, $0.45 \mathrm{M} \mathrm{NaCl}, 1 \%$ (wt/vol) SDS, $0.5 \%$ 
(wt/vol) nonfat dry milk, $0.5 \mathrm{mg} / \mathrm{ml}$ denatured salmon sperm DNA, 3 mM EDTA, $30 \mathrm{mM} \mathrm{NaH} \mathrm{PO}_{4}$ buffer, $\mathrm{pH}$ 7.4. Human insulin receptor cDNA fragments Eco R1 1,011 and 4,187 bp (27) were generously provided by Dr. Ora Rosen (Memorial-Sloan Kettering Cancer Center, New York, NY) and subcloned in SP 64 vectors. A 677-bp probe for the insulin receptor $\alpha$ subunit was generated by Xho I digestion of the 1,011-bp Eco R1 fragment; a 1,599-bp probe for the $\beta$ subunit was similarly produced by Pst I cleavage of the 4,187-bp Eco RI fragment. Probes were labeled with $\alpha-\left[{ }^{32} \mathrm{P}\right]-\mathrm{dCTP}$ to $\sim 1 \times 10^{9} \mathrm{dpm} / \mu \mathrm{g}$ using a random hexamer priming kit. Hybridization was for $16-20 \mathrm{~h}$ at $42^{\circ} \mathrm{C}$ in prehybridization solution. Blots were washed successively in $2 \times$ SSC, $0.1 \%$ SDS, $0.5 \times$ SSC, $0.1 \%$ SDS and $0.1 \times$ SSC, $0.5 \%$ SDS at room temperature followed by $0.1 \times \mathrm{SSC}, 0.5 \% \mathrm{SDS}$ for $30 \mathrm{~min}$ at $50^{\circ} \mathrm{C}$ before autoradiography at $-80^{\circ} \mathrm{C}$.

\section{Results}

Growth parameters. The growth characteristics of the endothelial cells from the diabetic and nondiabetic rats were compared. For cells derived from nondiabetic BB rats, the average doubling time was $18 \pm 1.3 \mathrm{~h}$ and the cell density at confluency was $(16.7 \pm 2.2) \times 10^{4}$ cells $/ \mathrm{cm}^{2}$ (mean and SD of three independent cell isolates). In contrast, endothelial cells from the diabetic animals grew slower, with a doubling time of $32.3 \pm 4.7$ h $(P<0.01)$ and had fewer cells at confluency $(11.9 \pm 0.9)$ $\times 10^{4}$ cells $/ \mathrm{cm}^{2}$ (Table I). A similar decrease in growth rate was observed in the cells harvested from streptozotocin-treated diabetic rats.

Biological effects of insulin. Because endothelial cells from the adipose tissue and other microvessels have been shown to be sensitive to insulin and IGF-I stimulation (13), the responsiveness of the endothelial cells from the diabetic and nondiabetic BB rats to insulin as measured by 2DG and AIB uptake was determined. Capillary endothelial cells from nondiabetic rats showed an increase of 2DG uptake when stimulated by insulin at $0.16 \mathrm{nM}$ and reached the maximum of $180 \%$ of basal at $160 \mathrm{nM}$ (Fig. 1). Surprisingly, in cells from diabetic animals there was no stimulation of 2DG uptake by insulin at any concentration (Fig. 1). Similarly, capillary endothelial cells from streptozotocin-treated rats did not respond significantly to insulin stimulation. Spermidine, which has been shown to increase glucose uptake into cells via a pathway that is probably distal to the insulin receptors had a similar stimulation of 2DG (50-70\% maximum, $n=3)$ uptake in both diabetic and nondiabetic cells (data not shown).

In addition to glucose uptake, insulin's effect on amino acid uptake was measured using [ $\left.{ }^{14} \mathrm{C}\right] \mathrm{AIB}$ with cells from nondiabetic rats, some stimulation of uptake was observed with an insulin concentration of $0.16 \mathrm{nM}$ and uptake reached its peak at $160 \mathrm{nM}$ (Fig. 2), in parallel with 2DG uptake. By contrast,

Table I. Growth Parameters in Capillary Endothelial Cells from BB Rats

\begin{tabular}{lccc}
\hline & Nondiabetic & Diabetic & $P$ \\
\hline $\begin{array}{l}\text { Doubling time }(h) \\
\text { Cell density at confluency } \\
\left(10^{4} \text { cells } / \mathrm{cm}^{2}\right)\end{array}$ & $18.03 \pm 1.3$ & $32.33 \pm 4.7$ & $<0.01$ \\
\hline
\end{tabular}

$P$ values were derived by paired $t$ test. Data shown here are mean \pm SD from three experiments.

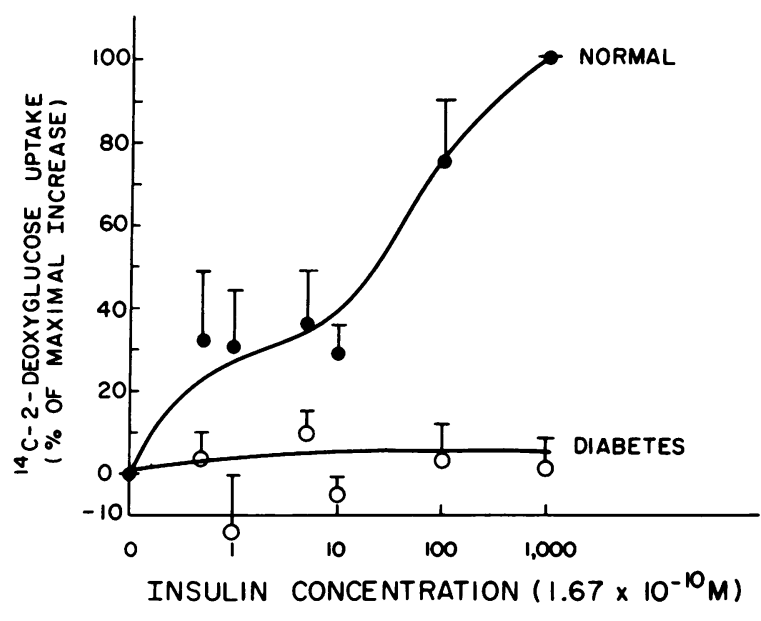

Figure 1. Dose response of insulin-stimulated 2DG uptake by capillary endothelial cells from (0) diabetic and (๑) nondiabetic BB rats. 2DG uptake was performed as described in Methods. Each point represents the mean and SE from three separate experiments using endothelial cells from three different groups of diabetic and nondiabetic BB rats. The difference in 2DG uptake between endothelial cells from diabetic and nondiabetic BB rats is significant at insulin concentrations of $1.6 \times 10^{-7} \mathrm{M}$ with a $P$ value $<0.01$ as analyzed by the paired $t$ test.

cells from the diabetic animals did not show any significant effect at any insulin concentration (Fig. 2).

$\left[{ }^{3} \mathrm{H}\right]$ Thymidine incorporation into $D N A$. The growth effects of insulin and IGF-I were studied by measuring $\left[{ }^{3} \mathrm{H}\right]-$ thymidine incorporation into DNA. In previous studies, insulin was reported to be less potent then IGF-I $(13,28)$. These findings are confirmed in this study. Insulin at $9 \times 10^{-7} \mathrm{M}$

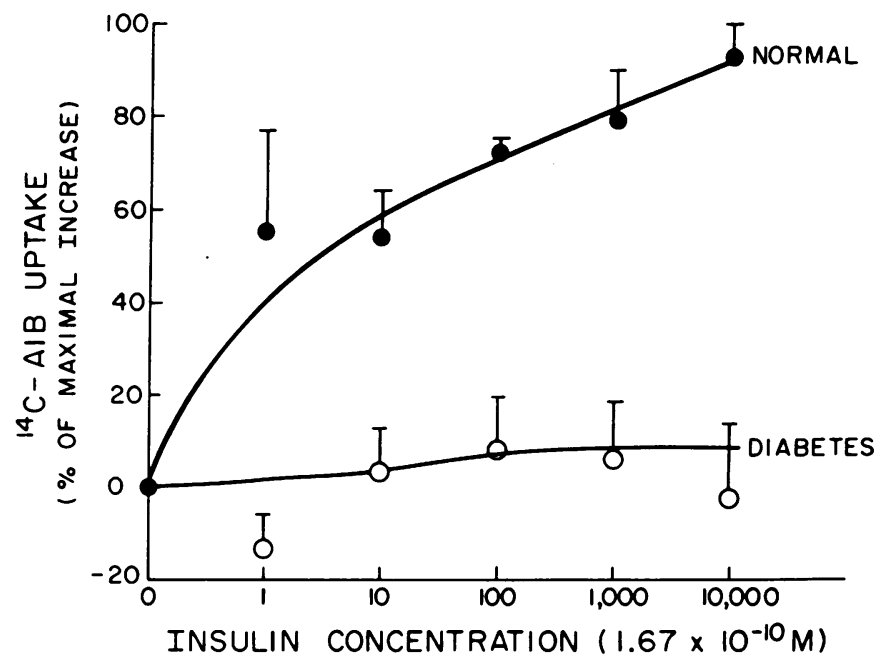

Figure 2. Dose response of insulin-stimulated $\alpha$-amino-isobutyric acid uptake by capillary endothelial cells from (0) diabetic and (๑) nondiabetic BB rats. $\alpha$-Amino-isobutyric acid uptake was performed as described in Methods. Each point represents mean and SE from three separate experiments using endothelial cells from three different groups of diabetic and nondiabetic BB rats. The differences in AIB uptake between endothelial cells from diabetic and nondiabetic $\mathrm{BB}$ rats are significant at insulin concentrations of $1.6 \times 10^{-6}, 1.6$ $\times 10^{-9}$, and $1.6 \times 10^{-10} \mathrm{M}$ with $P$ values $<0.03$ as analyzed by the paired $t$ test. 


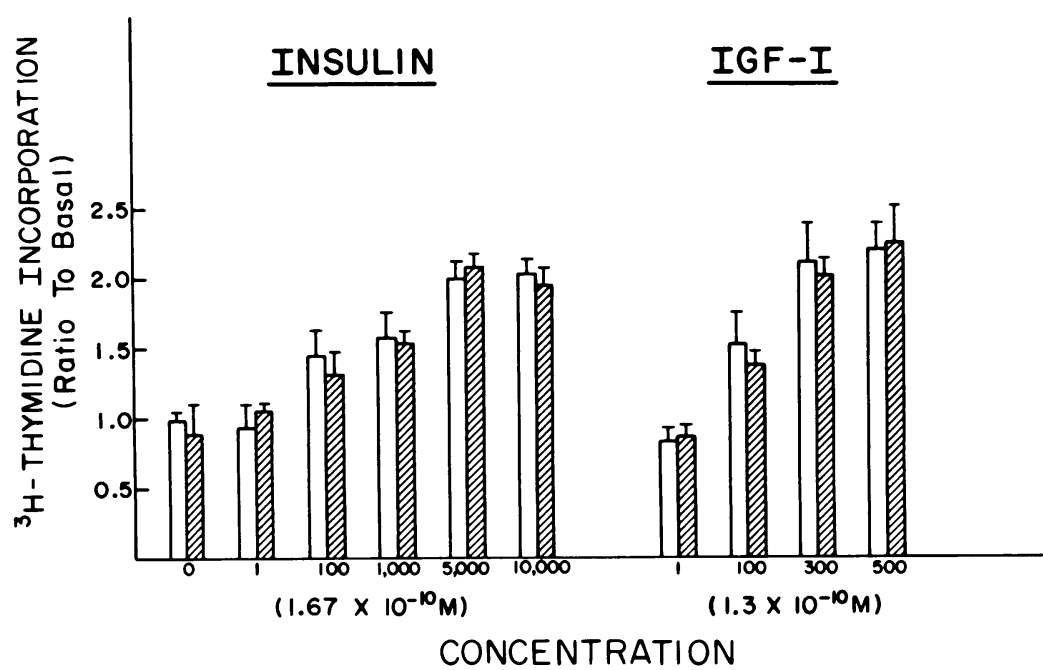

Figure 3. Dose response of insulin- and IGF-I-stimulated DNA synthesis as measured by $\left[{ }^{3} \mathrm{H}\right]$ thymidine incorporation in capillary endothelial cells from $(\square)$ diabetic and ( $\square$ ) nondiabetic BB rats. $\left[{ }^{3} \mathrm{H}\right]$ Thymidine incorporation was performed as described in Methods. Data shown here are mean and SE from three separate experiments. The difference between diabetic and nondiabetic is not significant. stimulated $\left[{ }^{3} \mathrm{H}\right]$ thymidine incorporation to the same extent as $4 \times 10^{-8} \mathrm{M}$ of IGF-I. Comparable maximums were obtained with insulin and IGF-I but at different concentrations. No difference in both insulin and IGF-I stimulated $\left[{ }^{3} \mathrm{H}\right]$ thymidine incorporation was found between cells from diabetic and nondiabetic rats (Fig. 3).

Insulin receptor. Because endothelial cells from diabetic rats of spontaneous origin (BB) and streptozotocin-induced rats were less responsive to insulin as compared with cells from nondiabetic animals, the insulin receptor on these cells was examined. ${ }^{125} \mathrm{I}$-insulin binding to cell surface receptors was decreased when the endothelial cells of diabetic rats were compared with those of nondiabetic rats. At tracer concentration, the endothelial cells from normal BB rats exhibited a $4.6 \pm 0.7 \%$ binding per milligram of cell protein, whereas endothelial cells cultured from diabetic rats bound only $2.6 \pm 0.4 \%$ per milligram protein, $(P<0.01)$ (Fig. 4). In cells from Sprague-Dawley rats, the diabetic and nondiabetic rats had $1.9 \pm 0.6$ and $3.4 \pm 0.4 \%$ per milligram protein, respectively. Scatchard analysis showed the change is due to receptor num- ber $\left(R_{\mathrm{o}}\right)$ changes. The dose-dependent inhibition of ${ }^{125} \mathrm{I}$-insulin binding by increasing concentration of unlabeled insulin was similar in both nondiabetic and diabetic endothelial cells from $\mathrm{BB}$ rats with $50 \%$ inhibition at 0.8 and $0.6 \mathrm{nM}$, respectively. Scatchard analysis of the competition curve showed no change in affinity $\left(K_{\mathrm{a}}\right)$, but the $R_{\mathrm{o}}$ appeared to be lower in cells from diabetic rats by $50 \%$. By comparison, IGF-I binding was two to three times greater than insulin binding, but showed no change in cells from diabetic rats; specific binding was $16.7 \pm 1.2$ vs. $15.3 \pm 2 \%$ per milligram protein (Fig. 5). No difference was found between cells from diabetic and nondiabetic rats. In addition, fibroblasts from the fatty tissue were also cultured and their insulin receptor binding were compared. No significant differences were observed between cells from diabetic and nondiabetic rats, $1.8 \pm 0.5$ versus $1.4 \pm 0.6 \%$ milligram protein, respectively (SE, $n=3$ ). Concentrations for $50 \%$ displacement of ${ }^{125} \mathrm{I}$-insulin were similar at 1.2 and $1.0 \times 10^{-9} \mathrm{M}$ respectively, for diabetic and nondiabetic rats. Scatchard analysis of the competition curve showed the derived $R_{\mathrm{o}}$ and $K_{\mathrm{d}}$ did not differ between these two groups of rats. These data suggested

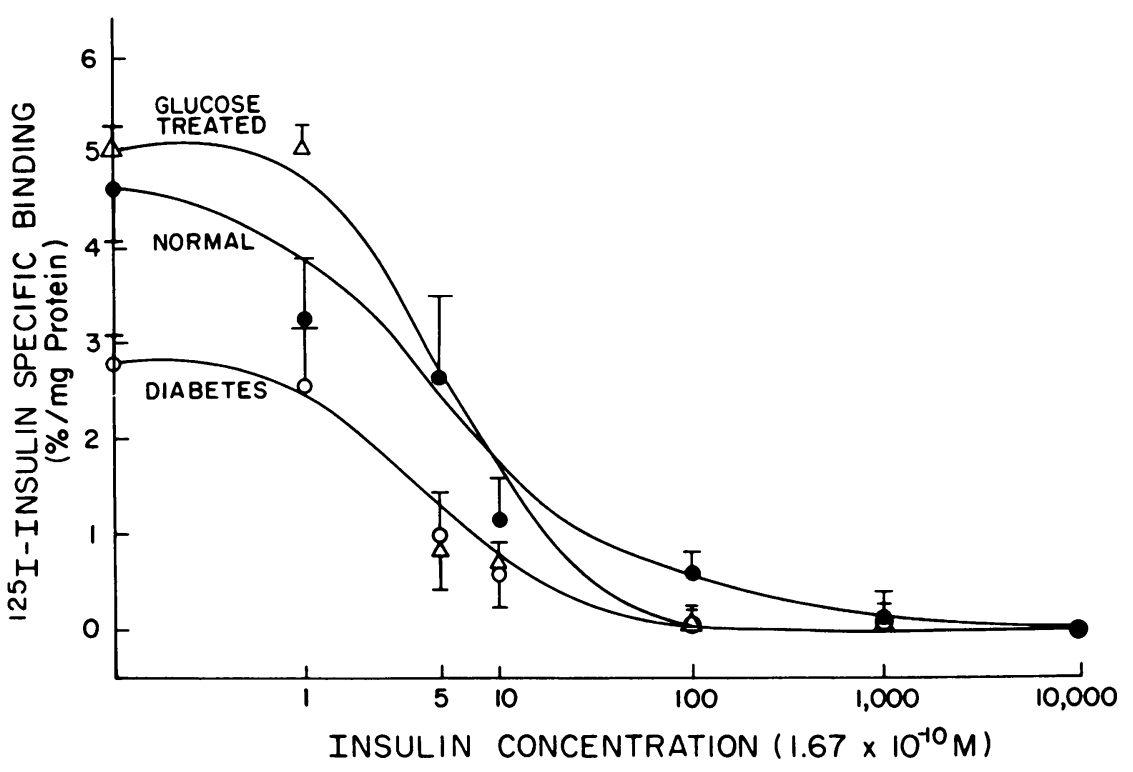

Figure 4. Competitive inhibition curves of insulin binding to intact capillary endothelial cells of $(0)$ diabetic and $(\bullet)$ nondiabetic BB rats and $(\Delta)$ cells from nondiabetic rats and treated with high glucose $(400 \mathrm{mg} / \mathrm{dl})$ for $1-10$ mo in culture. Insulin binding to endothelial cells was performed as described in Methods. The specific binding was calculated by subtracting the amount of radioactivity bound in the presence of $1.6 \times 10^{-6} \mathrm{M}(10 \mu \mathrm{g} / \mathrm{ml})$ of unlabeled porcine insulin from the total radioactivity bound to cells. Each point represents mean and SE from five separate experiments using endothelial cells from five different groups of diabetic and nondiabetic BB rats. 


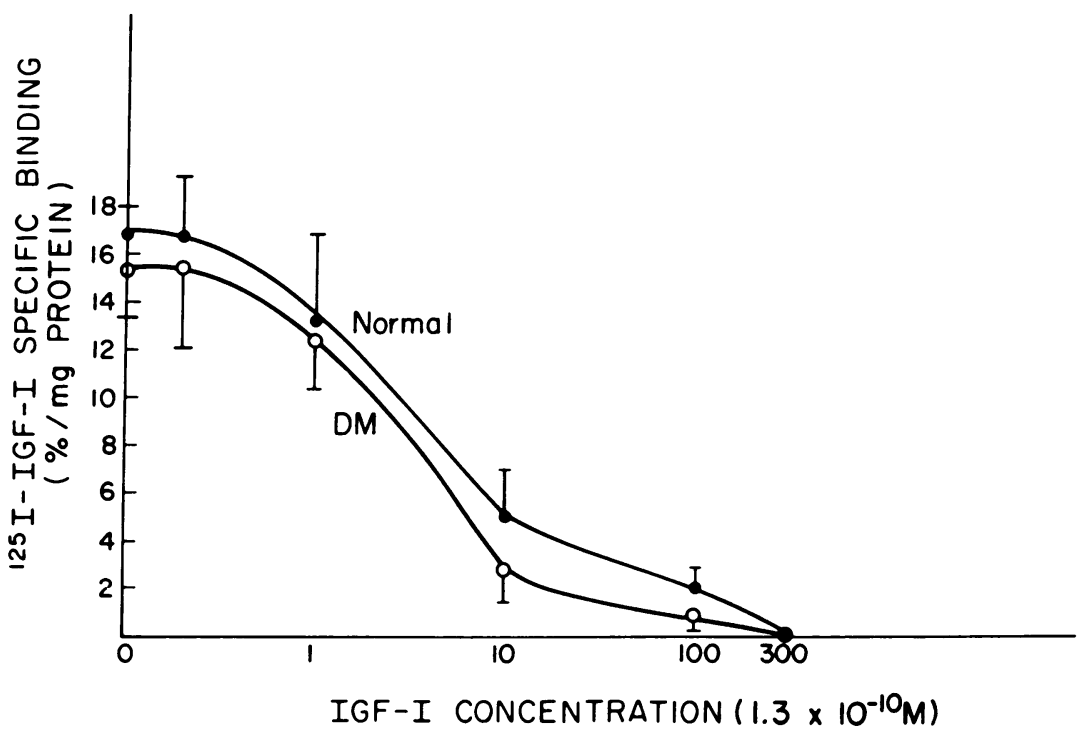

Figure 5. Competition inhibition curves of IGF-I binding to intact capillary endothelial cells of $(0)$ diabetic and $(\bullet)$ nondiabetic BB rats. IGF-I binding to endothelial cells was performed as described in Methods. The specific binding was calculated by subtracting the amount of radioactivity bound in the presence of $4 \times 10^{-8} \mathrm{M}(300 \mathrm{ng} / \mathrm{ml})$ of unlabeled IGF-I from the total radioactivity bound to cells. Data shown here are from three separate experiments, using endothelial cells from three different groups of diabetic and nondiabetic BB rats. that the binding defect in endothelial cells from diabetic rats was specific to insulin receptor.

The insulin receptor $\alpha$ and $\beta$ subunits were further characterized biochemically. The $\alpha$ subunit of the insulin receptor was examined by affinity cross-linking studies by covalently coupling bound ${ }^{125}$ I-insulin to the receptor with DSS and examining the solubilized receptor complexes by SDS-PAGE and autoradiography. Under reducing conditions $(0.1 \mathrm{M}$ DTT), a band at molecular mass of $\sim 140 \mathrm{kD}$ was observed on the autoradiogram of capillary endothelial cells from both diabetic and nondiabetic BB rats (Fig. 6). This band corresponds to the $\alpha$ subunit of the insulin receptor observed in other endothelial or nonendothelial tissues, although the apparent molecular weight of the receptor in endothelial cells is slightly higher than that in nonendothelial tissues. In addition, the major intense band or bands at $>200 \mathrm{kD}$ were found that had been reported by us previously as cross-linked $\alpha$ subunit of the insulin receptor (30). However, affinity labeling studies using divalent agents are not quantitative, because of uncertainty of the cross-linking efficiency in each experiment.

As a $50 \%$ decrease of insulin binding cannot account quantitatively for the severely impaired metabolic response to insulin in endothelial cells from diabetic BB rats, we further examined the kinase activity of the $\beta$ subunit, which is believed to initiate some, if not all, of the biological actions of insulin (29). The protein kinase activity of the $\beta$ subunit of the insulin receptor was examined using Triton X-100-solubilized and wheat-germ purified cell extract incubated with $\gamma^{32} \mathrm{P}$-ATP and $\mathrm{Mn}^{2+}$ in the presence and absence of insulin. The receptors were then identified by immunoprecipitation with an antireceptor antibody (B9 serum), SDS-PAGE, and autoradiography. A band with a molecular mass of $95 \mathrm{kD}$ that exhibited insulin-stimulated phosphorylation was observed in cells from nondiabetic animals (Fig. 7). A variable band at $100 \mathrm{kD}$ can also be observed and does not appear to be stimulated by insulin. In contrast, a smaller band at $88-90 \mathrm{kD}$ was observed in endothelial cells from diabetic animals (Fig. 7). Both bands are believed to be the $\beta$ subunit of the insulin receptor because they were stimulated by insulin and precipitated by anti-insulin receptor antibody. Quantitation of autophosphorylation by densitometric scanning of these bands showed that in nondia- betic cells, insulin stimulated the phosphorylation of the receptor over a range of concentrations from 0.16 to $160 \mathrm{nM}$, reaching a maximal on the average at eight times basal (Fig. 8). Insulin-stimulated phosphorylation of the insulin receptor was also detected in cells from diabetic BB rats, but only at insulin concentrations of $1.6 \mathrm{nM}$ or higher, and the maximal stimulation was decreased by $62 \%(P<0.05)$. However, the range of the decrease is very wide, from 45 to $11 \%$. The concentration for half-maximal stimulation appears to be higher for the cells from diabetic animals, although statistically the differences

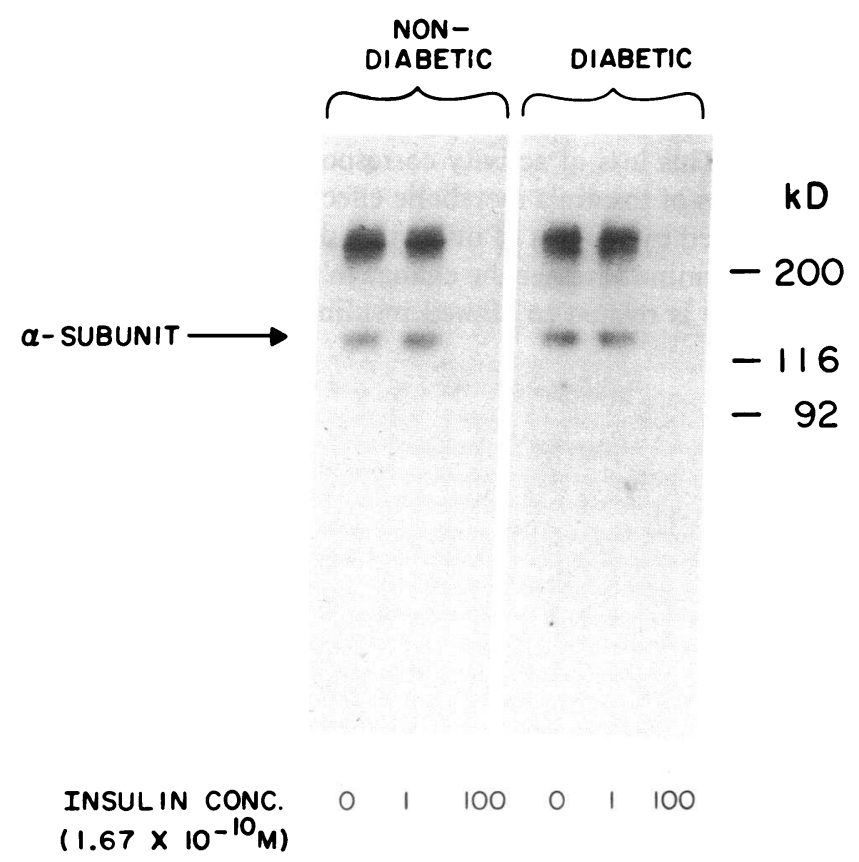

Figure 6. Autoradiogram of ${ }^{125} \mathrm{I}$-insulin-cross-linked insulin receptors from capillary endothelial cells of nondiabetic (left three lanes) and diabetic (right three lanes) BB rats. Cross-linking was performed as described in Methods. The $140-\mathrm{kD}$ band, as shown by the arrow, is the $\alpha$ subunit of insulin receptor. The molecular mass standards used were: myosin, $200 \mathrm{kD} ; \beta$-galactosidase, $116 \mathrm{kD}$; and phosphorylase B, $92.5 \mathrm{kD}$. 


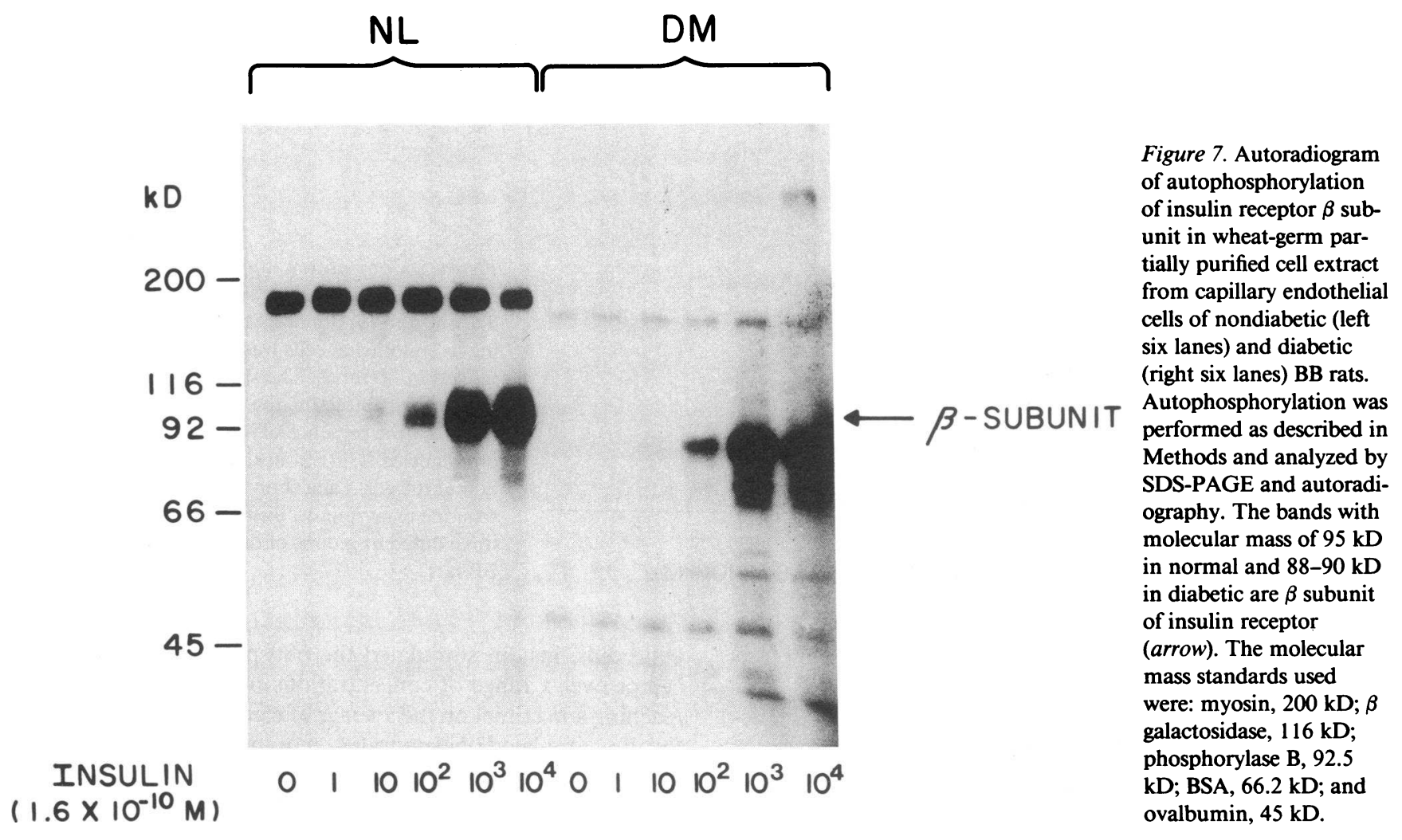

were not significant because of the large interexperimental variations found. Table II summarized the findings of insulinstimulated phosphorylation of various preparations of insulin receptors from capillary endothelial cells of diabetic and nondiabetic BB rats. As shown, both the potency and maximum amounts of tyrosine phosphorylation of the insulin receptors in intact cells, whole cell extracts, or wheat-germ purified were decreased. This loss of activity corresponds to the loss of responsiveness of insulin's metabolic effects, but is greater than that predicted by the loss of insulin binding.

To determine whether the change in the insulin receptor $\beta$ subunit size is related to altered insulin receptor mRNA ex-

pression, Northern blot analysis of insulin receptor mRNAs in endothelial cells from control and diabetic BB rats was performed. Two mRNA species of 9.4 and $7.2 \mathrm{~kb}$ were revealed using an $\alpha$ subunit sequence probe (Fig. 9). Identical hybridization was observed when this blot was washed and rehybridized with a $\beta$ subunit sequence probe (data not shown). For cells from both control and diabetic animals, the two receptor mRNA species are present in the same relative amounts (the 9.4-kb species representing $30 \%$ of total receptor mRNA). No abnormal mRNA species could be detected in the cells from diabetic rats. Receptor mRNA abundance was also identical for each cell line when expressed by densitometric scanning

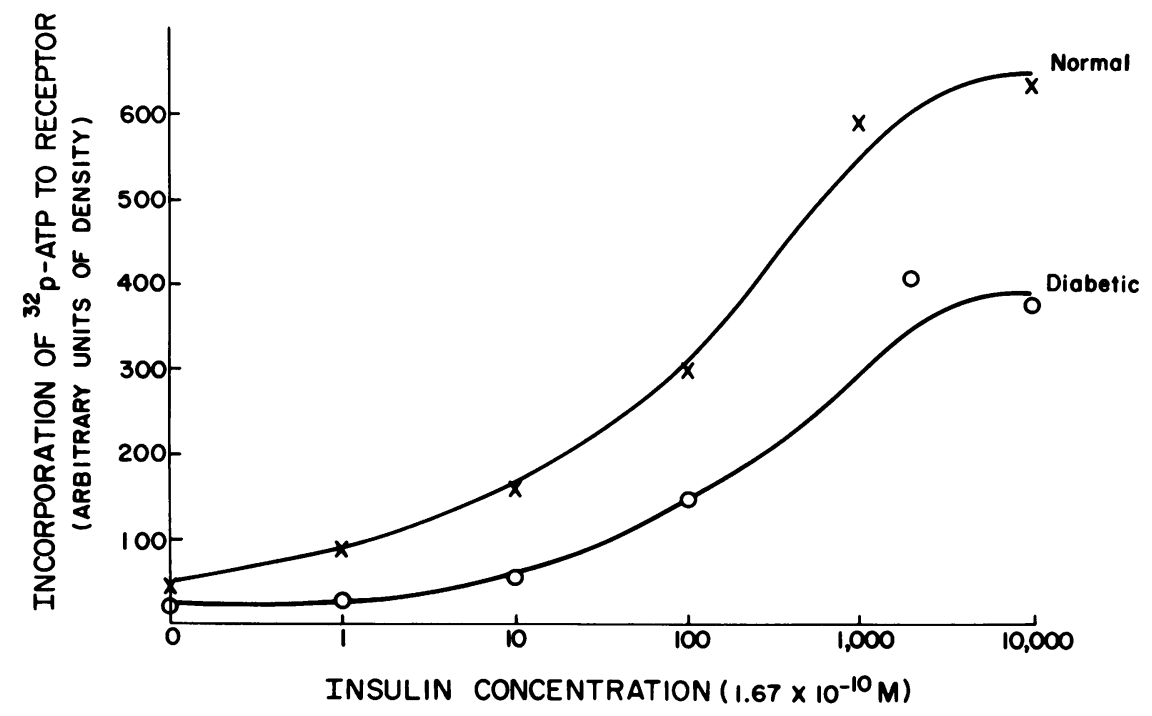

Figure 8. Dose response curves of insulin receptor autophosphorylation using partially purified receptor from capillary endothelial cells of $(0)$ diabetic and $(\bullet)$ nondiabetic BB rats. The bands correspond to $\beta$ subunit in the autoradiograms were quantitated by densitometric scanning and expressed in arbitrary unit. The data shown here are average from two separate experiments. More than five other experiments using different preparations of partially purified insulin receptor from endothelial cells from other groups of diabetic BB rats showed the same degree of impairment in maximal stimulated (insulin concentration: $1.6 \times 10^{-7}$ to $1.6 \times 10^{-6} \mathrm{M}$ ) autophosphorylation. 
Table II. Summary of Insulin Receptor Autophosphorylation in Capillary Endothelial Cells from Diabetic (DM) and Normal (NL) BB Rats

\begin{tabular}{|c|c|c|c|c|c|c|}
\hline \multirow{3}{*}{$\begin{array}{l}\text { Insulin } \\
\text { concentration }\end{array}$} & \multicolumn{6}{|c|}{$\begin{array}{l}\text { Type of insulin receptor preparation for phosphorylation } \\
\text { (fold increase, mean } \pm \text { SE) }\end{array}$} \\
\hline & \multicolumn{2}{|c|}{ Intact cell } & \multicolumn{2}{|c|}{ Whole cell extract } & \multicolumn{2}{|c|}{ WGA purified } \\
\hline & NL & DM & NL & DM & NL & DM \\
\hline \multicolumn{7}{|l|}{$n g / m l$} \\
\hline 10 & 0 & 0 & $2 \pm 1$ & 0 & $3 \pm 1$ & $1 \pm 1$ \\
\hline 100 & $4 \pm 2$ & $1 \pm 1$ & $4 \pm 2$ & $2 \pm 2$ & $4 \pm 2$ & $2 \pm 1$ \\
\hline 1,000 & $7 \pm 3^{*}$ & $4 \pm 3$ & $7 \pm 4$ & $6 \pm 3$ & $6 \pm 2$ & $3 \pm 2$ \\
\hline \multirow[t]{2}{*}{10,000} & $8 \pm 2 *$ & $4 \pm 2$ & $9 \pm 2 *$ & $4 \pm 2 *$ & $7 \pm 2^{*}$ & $3 \pm 2 *$ \\
\hline & \multicolumn{2}{|c|}{$n=4$} & \multicolumn{2}{|c|}{$n=10$} & \multicolumn{2}{|c|}{$n=5$} \\
\hline
\end{tabular}

The method for the studies and the preparation of receptors were described in Methods.

${ }^{*} P<0.05$ by $t$ test.

units per microgram of poly $\left(\mathrm{A}^{+}\right) \mathrm{RNA}$ applied to the gel (437 $\mathrm{U} / \mu \mathrm{g}$ for control cells vs. $450 \mathrm{U} / \mu \mathrm{g}$ in diabetic rat-derived cells). The nature of the two mRNA species is not currently known. However, these two bands are identical to those observed in a variety of rat tissues (31), and probably differ in $5^{\prime}$ or $3^{\prime}$ untranslated sequences. These findings indicate that there is no major alteration of insulin receptor mRNA structure or abundance in the cells from diabetic animals.

Effect of neuraminidase on the size of insulin receptors. Since the Northern analysis suggested that the protein cores

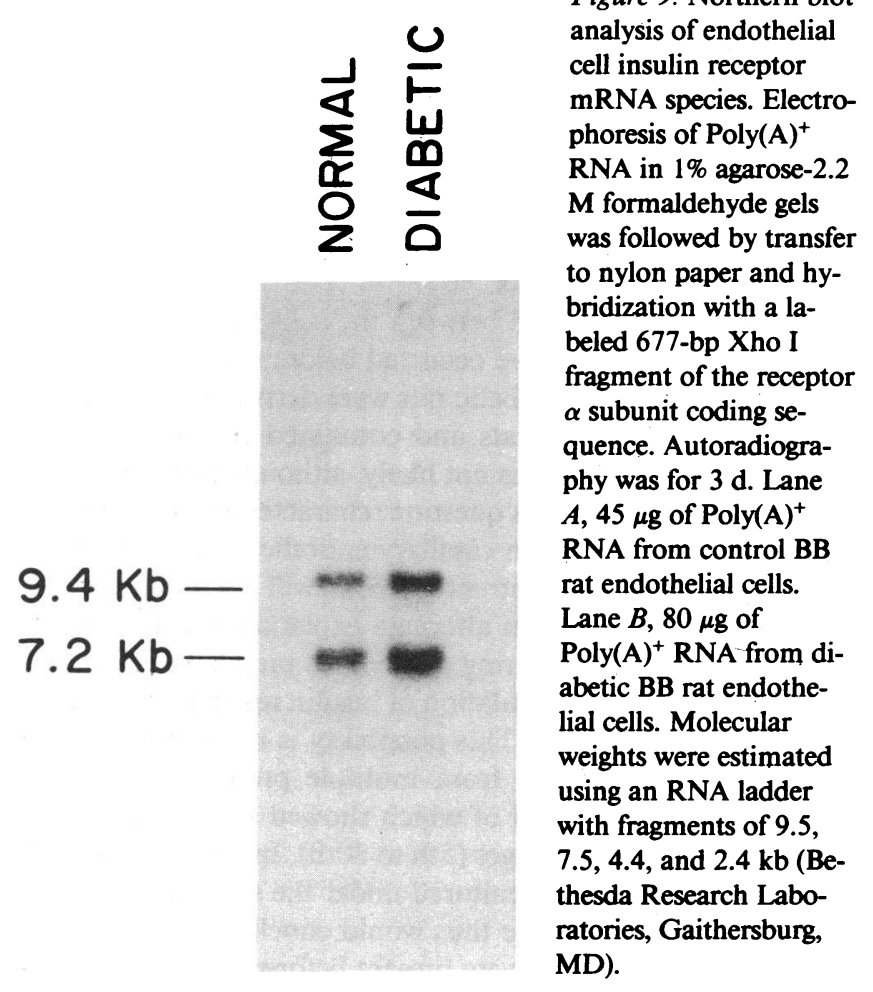

are not significantly different, we evaluated the possibility that the carbohydrate side chain could be altered. Neuraminidase is an exoglycosidase that removes the terminal sialic acid residues from the carbohydrate moiety of glyco-proteins. When digested with neuraminidase, the $\beta$ subunit of the insulin receptors from cells of nondiabetic rats had a decrease of molecular weight from 95 to $88 \mathrm{kD}$, whereas a much smaller change was observed for cells of diabetic rats, 90 to $88 \mathrm{kD}$ (Fig. 10).

Effect of hyperglycemia on insulin binding and receptor function. Because elevated glucose levels have been reported to alter the growth properties of endothelial cells (32), we examined the possibility that chronic hyperglycemia in vivo may be a causal factor for the alteration of the insulin receptor's binding and function. Capillary endothelial cells were exposed to $400 \mathrm{mg} / \mathrm{dl}$ of glucose for 3-10 mo and their insulin receptors were characterized by binding (Fig. 4), phosphorylation, and function with respect to 2DG uptake. As shown in Fig. 4 and Table III, elevated glucose at this level did not alter the properties of insulin receptors. In addition, the growth of capillary endothelial cells exposed to glucose levels of 100 and $400 \mathrm{mg} \%$ did not differ, even after 10 mo of exposure.

\section{Discussion}

The pathogenesis of diabetic microangiopathy appears to be metabolic, because the severity of the retinopathy is associated with glycemic control of diabetic patients over a chronic duration (34). Genetic susceptibility may still play a role, however (35).

This study represents the first report on capillary endothelial cells from animals with diabetes. Cells from diabetic BB rats were found to have a slower growth rate than the nondiabetic controls, consistent with previous studies $(6,7,36)$ reporting altered growth properties in fibroblasts cultured from diabetic patients, although contrasting findings have also been reported $(37,38)$. Interestingly, smooth muscle cells cultured from diabetic BB rats have been shown to have a more rapid growth rate and greater density at confluence (8). The reason for this discrepancy is unknown, although factors such as disease heterogeneity, duration, and difference in the types of cells used, could be responsible. The simultaneous findings of abnormalities in cellular growth and insulin actions could be coincidental. Alternatively, it is also possible that they are closely associated, since the absence of an insulin effect could be part of a general loss of nutrient uptake functions, such as glucose and amino acid transport, which are needed for cellular proliferation.

Surprisingly, the studies on the endothelial cells from diabetic BB rats cultured for up to 30 passages still manifested abnormalities in receptor sizes and function. The decrease in receptor binding is due to a decrease in total number of surface binding sites per milligram protein. Furthermore, the changes are not due to exposure to elevated glucose levels directly because chronic incubation of endothelial cells in high glucose medium did not reproduce this defect. It is possible that the decrease of insulin receptor could be due to 2 mo of insulin treatment before the diabetic rats were killed. However, this is unlikely since the decrease in binding remained in the capillary endothelial cells after long-term culturing. In addition, the cells from streptozotocin-induced diabetic rats also showed decrease in insulin-binding and action though insulin treatment was not used. 


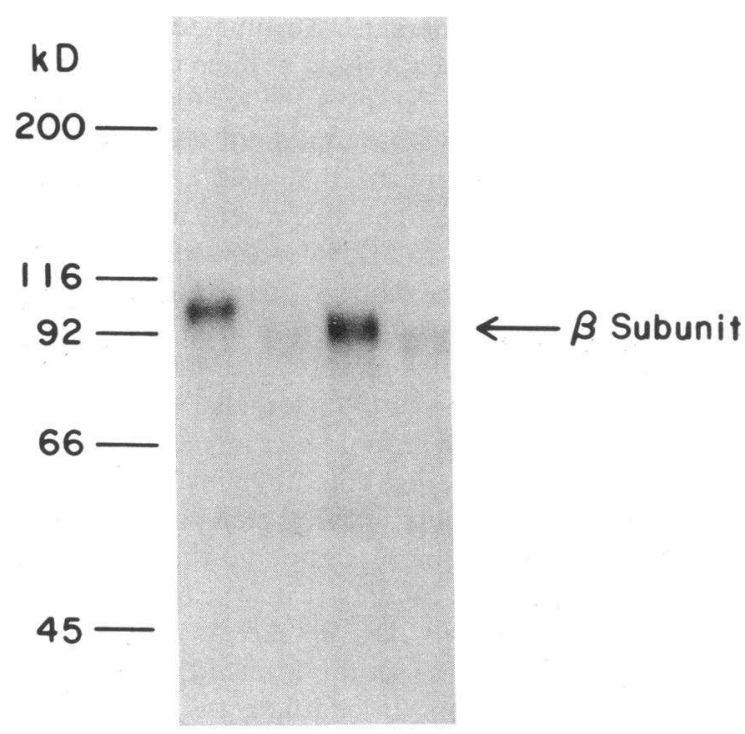

Neuraminidase --++

Figure 10. Effect of neuraminidase on WGA-purified insulin receptor $\beta$ subunit of endothelial cells from diabetic and nondiabetic BB rats. The details of the study is described in Methods. Receptors from nondiabetic rats with (lane 1) and without (lane 3) neuraminidase treatment. Lanes 2 and 4 represented receptors from diabetic rats.

The decrease in the receptor number is also reflected in insulin metabolic effects as measured by 2DG and AIB uptakes, estimating glucose and amino acid uptake, respectively. Endothelial cells from nondiabetic rats and bovine have been shown to be sensitive to insulin for metabolic effects, such as glucose transport, glucose incorporation into glycogen, and amino acid transport $(13,40)$. In contrast, Corkey et al. (41)

Table III. Effect of High Glucose on Insulin Action and Receptor in Cultured Capillary Endothelial Cells from Nondiabetic BB Rats

\begin{tabular}{lcc}
\hline & \multicolumn{2}{c}{ Glucose concentration } \\
\cline { 2 - 3 } & $100 \mathrm{mg} / \mathrm{dl}$ & $400 \mathrm{mg} / \mathrm{dl}^{*}$ \\
\hline Insulin binding & & \\
$\quad$ Total (\%/mg) & $4.6 \pm 0.7$ & $5.1 \pm 0.2$ \\
50\% displacement $(n M)$ & 0.8 & 1.1 \\
Insulin stimulated 2-DG uptake & & \\
$\quad$ Maximal (ratio to basal) & 1.8 & 1.4 \\
50\% stimulation $(n M)$ & 3.4 & 3.8 \\
Molecular weight of insulin receptor & & \\
$\quad$ (by SDS-PAGE) & & 140 \\
$\alpha$ subunit $(k \mathrm{D})$ & 95 & 95 \\
$\beta$ subunit $(k \mathrm{D})$ & & \\
Insulin-induced autophosphorylation & 8.5 & 5.2 \\
Maximal (ratio to basal) & 250 & 125 \\
50\% stimulation $($ nM) & & \\
\hline
\end{tabular}

* Cells had been exposed to high glucose concentrations $(400 \mathrm{mg} / \mathrm{dl})$ for 3-10 mo.

${ }^{\ddagger}$ Higher insulin concentration was needed to achieve $50 \%$ stimulation because crude cell extracts were used instead of the partially purified receptor. demonstrated that insulin did not influence hexose uptake in normal or transformed human umbilical vein endothelial cells and arterial endothelial cells, suggesting endothelial cells from capillary and arterial sources respond to insulin in different ways. In fact, King et al. (40) have reported differential responsiveness to insulin of endothelial cells from bovine macro- and microvessels when studied under the same conditions.

Insulin's effects on both glucose and amino acid uptake were severely impaired in endothelial cells from diabetic rats as compared with normal rats. Because spermidine's effect on inducing 2DG uptake is normal, the defect in the endothelial cells from diabetic rats is probably not due to alteration in the glucose transportation but located in or near the insulin receptors. However, the defects in insulin-stimulated metabolic effects cannot be accounted for by the decrease in insulin binding alone, since both the insulin sensitivity and responsiveness were impaired to a much greater degree than binding defects, suggesting the presence of postbinding defects (42) in endothelial cells from diabetic rats. This was further confirmed by the finding that the insulin-stimulated phosphorylation of the $\beta$ subunit of insulin receptor, one of the earliest events that occurs upon binding of insulin (43), was also decreased in endothelial cells from diabetic rats to a greater degree and comparable to the defect observed in insulin's effect. Since the defect in phosphorylation correlates in severity with the loss of metabolic effects of insulin, this postbinding defect could be responsible for the impairment of metabolic effects of insulin, although postreceptor defects were not excluded.

In contrast to the severe impairment of the metabolic actions of insulin (2DG and AIB uptake) found in diabetic cells, the growth promoting effects of insulin as measured by $\left[{ }^{3} \mathrm{H}\right]-$ thymidine incorporation was not different when cells from nondiabetic and diabetic rats were compared. This could be partly explained by the presence of unaltered IGF-I receptors on the endothelial cells, because the growth-promoting effects of insulin in endothelial cells may be mediated through the IGF-I receptor, which insulin can bind at with low affinity (13, 44-46). The finding that IGF-I is apparently more potent than insulin supports this possibility. However, more studies are needed to confirm this speculation. Since in other capillary endothelial cells, insulin can be equally potent with IGF-I in its mediating growth effects (13). We are providing these data to show that not all the actions of insulin are affected in endothelial cells from diabetic rats.

The differences found between the cells from diabetic and nondiabetic rats may have occurred before the rats developed diabetes. Because the diabetic rats were derived from the same parents as the control rats and contained the same genetic material, this possibility is not likely, although not completely excluded. To answer this question, characterization of insulin action and its receptor in capillary endothelial cells from rats rendered diabetic with streptozotocin will be helpful and is currently in progress. An alternate explanation for these differences is that the culturing procedures may have resulted in the isolation of a subpopulation of insulin resistant endothelial cells from diabetic rats. This possibility is minimized but not excluded by using cells from multiple preparations from a large number of rats, all of which showed similar findings in both early and late passages (5th to 30 th). In addition, the cells from diabetic rats were cultured under the same conditions as the nondiabetic cells. We thus would conclude that the differences between the cells were present before the in vitro cultur- 
ing of cells and postulate that the diabetic milieu in vivo has converted the capillary endothelial cells from an insulin-sensitive to -resistant state.

The alterations of insulin binding and action, and decreased tyrosine kinase activity were also found to be associated with a change in the $\beta$ subunit electrophoretic mobility migration rate, suggesting changes in its structure. This association could be coincidental. However, it is also possible that the decrease in size of $\beta$ subunit is responsible for the defects in insulin binding, action and phosphorylation. The difference in $\beta$ subunit size is apparently not due to a major alteration in receptor gene expression, because the Northern analysis showed no obvious difference between capillary cells from diabetic and nondiabetic $\mathrm{BB}$ rats. However, this study does not rule out small changes in the RNA sequences that may not alter cDNA hybridization. Translational control and/or posttranslational modifications affecting both size and abundance of the receptor $\beta$ subunit are more likely to account for the alterations observed in endothelial cells from the diabetic BB rats. Posttranslational changes could occur at the level of enzymatic glycosylation of the $\beta$ subunit or other structural modifications of the peptide. The neuraminadase data further supports the likelihood of a posttranslational modifications in the glycosylation step. Further studies focused on peptide mapping and the carbohydrate moieties of the insulin receptor $\beta$ subunit in capillary endothelial cells from diabetic animals and patients are in progress. The findings in the endothelial cells appear to be unusual among the various cells studied in the diabetic BB rats and other diabetic models. Previous studies by Okamoto et al. (47) did not reveal a molecular size change but did reveal tyrosine kinase activity changes. In addition, fibroblasts for the diabetic rats did not show any binding alterations. These findings would suggest that the changes in molecular size and actions of insulin receptors may be unique in the endothelial cells. Note that the insulin receptor in endothelial cells has the unusual property of processing insulin for the transcytosis pathway $(18,46,48)$. It thus would be tempting to suggest these two processes may be related.

The connection between this loss of insulin regulation in the capillary endothelial cells from diabetic rats to the development of diabetic microangiopathy will require further studies.

\section{Acknowledgments}

The authors would like to thank Terri-Lyn Bellman for her excellent secretarial assistance.

This work was supported by National Institutes of Health (NIH) grants EY-05110 to G.L. King, and DK-31036 to C.R.K. Dr. Kwok is the recipient of a grant from the American Diabetes Association/Lions Club International, Dr. Goldstein is a Pfizer Postdoctoral Fellow in Diabetes, and Dr. Muller-Wieland is a recipient of a fellowship from the Deutsche Forschungsgemeinschaft. This work was supported in part from the Tissue Culture Core services under NIH Diabetes and Endocrinology Research Center grant DK-36836.

\section{References}

1. Kohner, E. M. 1976. The problems of retinal blood flow in diabetes. Diabetes. 25(Suppl. 2):839-844.

2. Mogensen, C. E. 1971. Glomerular filtration rate and renal plasma flow in short-term and long-term juvenile diabetes mellitus. Scand. J. Clin. Lab. Invest. 28:91-100.

3. Williamson, J. R., and C. Kilo. 1981. The present status of basement membrane thickening in diabetes. In Microcirculation. $R$.
Effros, H. Schmid-Schonbein, and J. Ditzel, editors. Academic Press, Inc., New York. 191-204.

4. Cohen, M. P., M. L. Surma, and V. Y. Wu. 1982. In vivo biosynthesis and turnover of glomerular basement membrane in diabetic rats. Am. J. Physiol. 242:F385-389.

5. Kohner, E. M., and C. T. Dollery. 1975. Diabetic retinopathy. In Complications of Diabetes. H. Keen and J. Jarrett, editors. Edward Arnold, London. 7-98.

6. Vracko, R., and E. P. Benditt. 1975. Restricted replicative lifespan of diabetic fibroblasts in vitro: its relation to microangiopathy. Fed. Proc. 34:68-70.

7. Goldstein, S., E. J. Moerman, J. S. Soeldner, R. E. Gleason, and D. M. Barnett. 1979. Diabetes mellitus and genetic prediabetes, decreased replicative capacity of cultured skin fibroblasts. J. Clin. Invest. 63:358-370.

8. Bowersox, J. C., and N. Sorgente. 1985. Altered growth kinetics of dermal fibroblasts and arterial smooth muscle cells from spontaneously diabetic BB rats. Diabetes. 34:628-633.

9. Freidenberg, G. R., R. R. Henry, H. H. Klein, D. R. Reichart, and J. M. Olefsky. 1987. Decreased kinase activity of insulin receptors from adipocytes of non-insulin-dependent diabetic subjects. J. Clin. Invest. 79:240-250.

10. Comi, R. J., G. Grunberger, and P. Gorden. 1987. Relationship of insulin binding and insulin-stimulated tyrosine kinase activity is altered in Type II diabetes. J. Clin. Invest. 79:453-462.

11. Sinha, M. K., W. J. Pories, E. G. Flickinger, D. Meelheim, and J. F. Caro. 1987. Insulin-receptor kinase activity of adipose tissue from morbidly obese humans with and without NIDDM. Diabetes. 36:620-625.

12. Burant, C. F., M. K. Trentelaar, and M. G. Buse. 1986. Diabetes-induced functional and structural changes in insulin receptors from rat skeletal muscle. J. Clin. Invest. 77:260-270.

13. King, G. L., A. D. Goodman, S. M. Buzney, A. Moses, and C. R. Kahn. 1985. Receptors and growth promoting effects of insulin and insulin-like growth factors on cells from bovine retinal capillary and aorta. J. Clin. Invest. 75:1028-1036.

14. Like, A. A., L. Butler, R. M. Williams, M. C. Appel, E. A. Weringer, and A. A. Rossini. 1982. Spontaneous autoimmune diabetes mellitus in the BB rat. Diabetes. 31(Suppl. 1):7-13.

15. Sima, A. A. F., S. Chakrabarti, R. Garcia-Salinas, and P. K. Basu. 1985. The BB rat: an authentic model of human diabetic retinopathy. Curr. Eye Res. 4:1087-1092.

16. Brown, D. M., M. W. Steffes, P. Thibert, S. Azar, and S. M. Mauer. 1983. Glomerular manifestations of diabetes in the BB rat. Metab. Clin. Exp. 32(Suppl. 1):131-135.

17. Gimbrone, M. A., Jr. 1976. Culture of vascular endothelium. In Progress in Hemostasis and Thrombosis. Vol. 3. T. Spart, editor. Grune \& Stratton, Inc., New York. 1-28.

18. Hachiya, H. L., J. L. Carpentier, and G. L. King. 1986. Comparative studies on insulin-like growth factor II and insulin processing by vascular endothelial cells. Diabetes. 35:1065-1072.

19. Lowry, D. A., A. L. Rosebrough, A. L. Farr, and P. J. Randall. 1951. Protein measurements with the Folin phenol reagent. J. Biol. Chem. 193:265-275.

20. Ishibashi, F., H. Hidaka, B. V. Howard. 1982. Glucose enhancement of insulin action: elevated glucose levels increase insulin stimulation of 2-deoxyglucose uptake in cultured human fibroblasts. $J$. Clin. Endocrinol. \& Metab. 54:34-39.

21. Martin, M. S., and S. L. Pohl. 1979. Insulin-induced insulin resistance of $\alpha$-amino-isobutyric acid transport in cultured human skin fibroblasts. J. Biol. Chem. 254:9976-9978.

22. Rechler, M. M., J. M. Podskalny, I. D. Goldfine, and C. A. Wells. 1974. DNA synthesis in human fibroblasts stimulation by insulin and by nonsuppressible insulin-like activity. J. Clin. Endocrinol. \& Metab. 39:512-521.

23. Massague, J., and M. P. Czech. 1985. Affinity cross-linking of receptors for insulin and the insulin-like growth factors I and II. Methods Enzymol. 109:179-187. 
24. Kasuga, M., M. F. White, and C. R. Kahn. 1985. Phosphorylation of the insulin receptor in cultured hepatoma cells and a solubilized system. Methods Enzymol. 109:609-621.

25. Han, J. H., C. Stratowa, and W. J. Rutter. 1987. Isolation of full-length putative rat lysophospholipase cDNA using improved methods for mRNA isolation and cDNA cloning. Biochemistry. 26:1617-1625.

26. Aviv, H., and P. Leder. 1972. Purification of biologically active globin messenger RNA by chromatography on oligothymidylic acid cellulose. Proc. Natl. Acad. Sci. USA. 69:1408-1412.

27. Ullrich, A., J. R. Bell, G. Y. Chen, R. Herrera, L. M. Petruzzelli, T. J. Dull, A. Gray, L. Coussens, Y. C. Liao, M. Tsubokawa, A. Mason, P. H. Seeburg, C. Grunfeld, O. M. Rosen, and J. Ramachandran. 1985. Human insulin receptor and its relationship to the tyrosine kinase family of oncogenes. Nature (Lond.). 313:756-761.

28. Zapf, J., E. Schoenle, and E. R. Froesch. 1978. Insulin-like growth factors I and II: some biological actions and receptor binding characteristics of two purified constituents of nonsuppressible insulinlike activity of human serum. Eur. J. Biochem. 87:285-296.

29. Kahn, C. R. 1985. Insulin receptors. In The Diabetes Annual. Vol. 1. K. G. M. M. Alberti and L. P. Krall, editors. Elsevier Science Publishers, B. V. 446-462.

30. Jialal, I., M. Crettaz, H. L. Hachiya, C. R. Kahn, A. C. Moses, S. M. Buzney, and G. L. King. 1985. Characterization of the receptors for insulin and the insulin-like growth factors on micro- and macrovascular tissues. Endocrinology. 117:1222-1229.

31. Goldstein, B. J., D. Muller-Wieland, and C. Z. Kahn. 1987. Variation in insulin receptor messenger ribonucleic acid. Expression in human and rodent tissues. Mol. Endocrinol. 1:759-766.

32. Lorenzi, M., D. F. Montisano, S. Toledo, and A. Barrieux. 1986. High glucose induces DNA damage in cultured human endothelial cells. J. Clin. Invest. 77:322-325.

33. Arieff, A. I., and B. D. Myers. 1981. Diabetic nephropathy. In The Kidney. Brenner and Rector, editors. W. B. Saunders Co., Philadelphia, PA. 1906-1949.

34. Viberti, G., J. C. Pickup, R. W. Bilous, H. Keen, and D. Mackintosh. 1981. Correction of exercise induced micro-albuminuria in insulin-dependent diabetics after 3 weeks of subcutaneous insulin infusion. Diabetes. 30:818-823.

35. Rosenbloom, A. L., J. H. Silverstein, D. C. Lezotte, K. Richardson, and M. McCallum. 1981. Limited joint mobility in childhood diabetes mellitus indicated increased risk for microvascular disease. $N$. Engl. J. Med. 305:191-194.
36. Goldstein, S., J. W. Littlefield, and J. S. Soeldner. 1969. Diabetes mellitus and aging: diminished plating efficiency of cultured human fibroblasts. Proc. Natl. Acad. Sci. USA. 64:155-160.

37. Howard, B. V., R. M. Fields, D. M. Mott, P. J. Savage, M. Nagulesparan, and P. H. Bennett. 1980. Diabetes and cell growth: lack of differences in growth characteristics of fibroblasts from diabetic and non-diabetic Pima Indians. Diabetes. 29:119-124.

38. Raizada, M. K., G. Tan, and R. E. Fellows. 1980. Fibroblastic cultures from the diabetic $\mathrm{db} / \mathrm{db}$ mouse: demonstration of decreased insulin receptors and impaired responses to insulin. J. Biol. Chem. 255:9149-9155.

39. Berliner, J. A., H. J. L. Frank, D. Karasic, and M. Capadeville. 1984. Lipoprotein-induced insulin resistance in aortic endothelium. Diabetes. 33:1039-1044.

40. King, G. L., S. M. Buzney, C. R. Kahn, N. Hetu, S. Buchwald, S. G. MacDonald, and L. I. Rand. 1983. Differential responsiveness to insulin of endothelial and support cells from micro- and macrovessels. J. Clin. Invest. 71:974-979.

41. Corkey, R. F., B. E. Corkey, and M. A. Gimbrone, Jr. 1981. Hexose transport in normal and SV 40-transformed human endothelial cells in culture. J. Cell. Physiol. 106:425-434.

42. Kahn, C. R. 1978. Insulin resistance, insulin insensitivity and insulin unresponsiveness: a necessary distinction. Metab. Clin. Exp. 27(Suppl. 2):1893-1902.

43. Kahn, C. R. 1985. The molecular mechanism of insulin action. Annu. Rev. Med. 36:429-451.

44. Megyesi, K., C. R. Kahn, J. Roth, D. M. Neville, Jr., S. P. Nissley, R. E. Humbel, and G. R. Froesch. 1975. The NSILAs receptor in liver plasma membranes: characterization and comparison with the insulin receptor. J. Biol. Chem. 250:8990-8996.

45. King, G. L., C. R. Kahn, M. M. Rechler, and S. P. Nissley. 1980. Direct demonstration of separate receptors for growth and metabolic activities of insulin and multiplication stimulating activities. $J$. Clin. Invest. 66:130-140.

46. Banskota, N. K., J.-L. Carpentier, and G. L. King. 1986. Processing and release of insulin and insulin-like growth factor I by macroand microvascular endothelial cells. Endocrinology. 119:1904-1913.

47. Okamoto, M., M. F. White, R. Maron, and C. R. Kahn. 1986. Autophosphorylation and kinase activity of insulin receptor streptozotocin-induced and BB diabetic rats. Am. J. Physiol. E542-E550.

48. King, G. L., and S. Johnson. 1985. Receptor-mediated transport of insulin across endothelial cells. Science (Wash. DC). 227:1583-1586. 